\title{
KONDISI, PENDAPATAN DAN PERSEPSI MASYARAKAT TERHADAP KEBERADAAN USAHA SARANG BURUNG WALET \\ (Studi di Desa Rantau Katang, Kecamatan Telaga Antang, Kabupaten Kotawaringin Timur, Provinsi Kalimantan Tengah)
}

\author{
${ }^{1}$ Fahnur Reza, ${ }^{2}$ Evi Feronika Elbaar, ${ }^{3}$ Betrixia Barbara
}

\author{
${ }^{1}$ Alumnus Program Studi Agribisnis Fakultas Pertanian Universitas Palangka Raya \\ ${ }^{2,3}$ Staf Pengajar Program Studi Agribisnis Fakultas Pertanian Universitas Palangka Raya
}

\begin{abstract}
ABSTRAK
Persepsi adalah merupakan proses penilaian seseorang terhadap obyek tertentu. Persepsi masyarakat terhadap keberadaan usaha sarang burung walet di Desa Rantau Katang diperoleh dengan mengetahui kondisi usaha sarang burung walet, mengetahui pendapatan usaha sarang burung walet dan mengetahui persepsi masyarakat terhadap keberadaan usaha sarang burung walet dengan menggunakan skala likert dan rumus pendapatan. Hasil persepsi masyarakat menunjukan bahwa kondisi usaha sarang burung walet di Desa Rantau Katang adalah: pola pemanenan dilakukan rata-rata sebanyak 6 kali dalam setahun, rata-rata memiliki satu buah bangunan yang telah diusahakan 3-4 tahun, dan produksi didominasi oleh kualitas A. Rata-rata pendapatan usaha sarang burung walet di Desa Rantau Katang sebesar Rp. 60.025.000/tahun. Adapun rata-rata biaya total eksplisit adalah Rp. 3.775.000 dan penerimaannya adalah sebesar Rp. 63.800.000/tahun. Persepsi masyarakat di Desa Rantau Katang terhadap keberadaan usaha sarang burung walet adalah berada pada kategori "netral" dengan total persepsi 774 yang berarti responden memiliki sikap netral terhadap keberadaan usaha sarang burung walet di Desa Rantau Katang.
\end{abstract}

Kata kunci : Persepsi, Pendapatan, Usaha Sarang Burung Walet

\begin{abstract}
Perception is a process of evaluating someone against a particular object. The public perception of the existence of swift's nest business in Rantau Katang village was obtained by knowing the condition of swift's nest business, knowing the income of swift's nest business and knowing the community's perception of the existence of swift's nest business using the Likert scale and income formula. The results of public perception show that the condition of swift's nest business in Rantau Katang Village is: harvesting patterns are carried out on average 6 times a year, on average have one building that has been cultivated 3-4 years, and production is dominated by quality A. The average income of swift's nest business in Rantau Katang Village is Rp. 60,025,000 / year. The average total explicit cost is Rp. 3,775,000 and the receipt is Rp. 63,800,000 / year. The perception of the community in Rantau Katang village on the existence of swift's nest business is in the "neutral" category with an total perception of 774, which means that respondents have a neutral attitude towards the existence of swift's nest business in Rantau Katang Village.
\end{abstract}

Keywords: Perception, Revenue, Swift's Nest Business 


\section{PENDAHULUAN}

Usaha peternakan mempunyai prospek untuk dikembangkan karena tingginya permintaan akan produk peternakan. Usaha peternakan juga memberi keuntungan yang cukup tinggi dan menjadi sumber pendapatan bagi banyak masyarakat di perdesaaan di Indonesia. Salah satu usaha ternak yang mempunyai kemampuan untuk menghasilkan banyak keuntungan yaitu budidaya ternak burung walet.

Sarang walet memiliki prospek dan potensi perdagangan yang sangat bagus untuk dikembangkan. Saat ini Indonesia merupakan produsen sarang walet terbesar didunia. Mencapai lebih dari $75 \%$ sarang walet yang beredar di dunia berasal dari Indonesia. Sarang walet rumahan asal Indonesia menguasai hampir $98 \%$ pasokan pasar dunia karena bentuknya yang lebih bersih, lebih putih dan tidak terlalu tebal. Sementara pasar sarang walet hitam dipegang oleh Malaysia karena kualitasnya lebih baik dari pada sarang hitam yang diekspor oleh negara produsen lain. Sarang walet banyak diminta oleh importir terbesar saat ini yaitu Hongkong dan Amerika Serikat. Jangkauan pasar sarang walet asal Indonesia adalah Hongkong, China, Taiwan, Singapura, dan Kanada. Sekitar $80 \%$ pasar sarang walet Asia dipasok oleh produsen dari Indonesia. Sarang walet memiliki harga yang berfluktuasi. Ditingkat eksportir harga sarang walet hitam gua mencapai Rp3.500.000,00/kg, sarang rumput/seriti harganya sekitarRp. $2.500 .000 .00 / \mathrm{kg}$, harga sarang walet gua wama putih bisa mencapai Rp. $12.000 .000 .00 / \mathrm{kg}$ sedangkan sarang walet rumahan putih mencapai $\mathrm{Rp}$. $17.000 .000 .00 / \mathrm{kg}$. Harga sarang walet dapat terjadi perubahan setiap waktu tergantung dari hasil negosiasi dan kesepakatan (TRUBUS, 2009).
Budidaya burung walet belakangan ini terlihat makin marak. Di berbagai daerah di Indonesia selalu dijumpai bangunan khas untuk budidaya burung berliur mahal ini. Manusia sebagai makhluk sosial yang sekaligus juga makhluk individual, maka terdapat perbedaan antara individu yang satu dengan yang lainnya. Adanya perbedaan inilah yang antara lain menyebabkan mengapa seseorang menyenangi suatu obyek, sedangkan orang lain tidak senang bahkan membenci obyek tersebut. Hal ini sangat tergantung bagaimana individu menanggapi obyek tersebut dengan persepsinya. Pada kenyataannya sebagian besar sikap, tingkah laku dan penyesuaian ditentukan oleh persepsinya (Soehartono, 1995). Persepsi pada hakikatnya adalah merupakan proses penilaian seseorang terhadap obyek tertentu. Menurut Sunarto (2005) persepsi merupakan aktivitas mengindera, mengintegrasikan dan memberikan penilaian pada obyek-obyek fisik maupun obyek sosial, dan penginderaan tersebut tergantung pada stimulus fisik dan stimulus sosial yang ada di lingkungannya. Sensasisensasi dari lingkungan akan diolah bersama-sama dengan hal-hal yang telah dipelajari sebelumnya baik hal itu berupa harapan-harapan,nilai-nilai, sikap, ingatan dan lain-lain. Di dalam proses persepsi individu dituntut untuk memberikan penilaian terhadap suatu obyek yang dapat bersifat positif/negatif, senang atau tidak senang dan sebagainya.

Usaha sarang burung walet adalah salah satu usaha yang memang terbukti sangat menjanjikan. Namun demikian usaha sarang burung walet juga menuai pro dan kontra dikalangan masyarakat. Karena berbagai dampak yang ditimbulkan oleh kegiatan tersebut jika lokasi usaha berdekatan dengan permukiman penduduk. Dari banyaknya dampak yang disebabkan 
oleh bangunan sarang burung walet yang berdekatan dengan permukiman penduduk beberapa diantaranya adalah gangguan suara dari alat pemanggil burung walet, ancaman penyakit dan sebagainya.

Adapun tujuan dari penelitian ini adalah:

1. Mengetahui kondisi usaha sarang burung walet di Desa Rantau Katang, Kecamatan Telaga Antang, Kabupaten Kotim.

2. Mengetahui pendapatan usaha sarang burung walet di Desa Rantau Katang, Kecamatan Telaga Antang, Kabupaten Kotim.

3. Mengetahui persepsi masyarakat terhadap keberadaan usaha sarang burung walet di Desa Rantau Katang, Kecamatan Telaga Antang, Kabupaten Kotim.

\section{METODE PENELITIAN}

Penelitian ini dilaksanakan pada bulan Juni sampai dengan bulan Agustus 2018 di desa Rantau Katang, Kecamatan Telaga Antang, Kabupaten Kotawaringin Timur. Penelitian ini adalah penelitian survei. Populasi adalah pengusaha walet dan masyarakat di Desa Rantau Katang, Kecamatan Telaga Antang, Kabupaten Kotim. Metode pengambilan sampel dilakukan dengan purposive sampling adalah metode pengambilan sampel yang berdasarkan atas suatu pertimbangan tertentu seperti sifat-sifat populasi ataupun ciri-ciri yang sudah diketahui sebelumnya. (Notoadmodjo, 2010)

Sampel pada penelitian ini berjumlah 36 sampel masyarakat dan 5 pengusaha. Pertimbangan dalam memilih 5 orang pengusaha dikarenakan karakteristik yang sama dan pertimbangan mengambil 36 orang berdasarkan 2 orang mewakili masyarakat disekitar satu bangunan sarang burung walet. Sampel sebanyak 5 orang digunakan untuk mengetahui pendapatan usaha sarang burung walet di Desa Rantau Katang, dan sampel sebanyak 36 orang adalah untuk mengetahui persepsi masyarakat Desa Rantau Katang terhadap usaha sarang burung walet.

Data yang dikumpulkan selanjutnya akan ditabulasi/kompilasi dan diolah dalam bentuk tabulasi (tabel) yang kemudian dilakukan dengan alat hitung dan bantuan komputer dengan program sedangkan untuk pengamatan dilakukan secara deskriptif.

Untuk menjawab tujuan pertama, yaitu mengetahui kondisi usaha sarang burung walet di Desa Rantau Katang, Kecamatan Telaga Antang, Kabupaten Kotim, akan dilakukan dengan analisis deskriptif.

Selanjutnya untuk menjawab tujuan kedua, yaitu mengetahui dampak usaha sarang burung walet terhadap pendapatan pengusaha/masyarakat di Desa Rantau Katang, Kecamatan Telaga Antang, Kabupaten Kotim, menurut Soekartawi (1995) dapat dihitung dengan rumus :

$$
\mathbf{I}=\mathbf{T R}-\mathbf{T C}
$$

Keterangan :

I = Total pendapatan yang diperoleh pengusaha walet (Rp).

$\mathrm{TR}=$ Total revenue atau penerimaan yang diperoleh pengusaha walet (Rp).

TC = Biaya yang dikeluarkan pengusaha walet $(\mathrm{Rp})$.

$$
\mathbf{T R}=\mathbf{Y i}+\mathbf{P y i}
$$

Keterangan :

TR $=$ Penerimaan Total $(\mathrm{Rp})$.

$\mathrm{Yi} \quad=$ Output (sarang burung walet $)(\mathrm{Kg})$

$$
\begin{gathered}
\text { Pyi }=\text { Harga output yang } \\
\text { dihasilkan }(\mathrm{Rp} / \mathrm{Kg})
\end{gathered}
$$

TC yang dimaksud dalam penelitian ini adalah totan biaya eksplisit yang dikeluarkan pengusaha walet (rupiah/periode), yang secara matematis dapat ditulis sebagai berikut :

$$
T C=\sum_{i=1}^{n} X i . P x i
$$


Keterangan:

$$
\begin{aligned}
& \mathrm{TC}=\text { Biaya Total (Total Cost }) \\
& \mathrm{Xi}=\text { Jumlah Input } \\
& \mathrm{Pxi}=\text { Harga Input } \\
& \mathrm{i}=1,2,3, \ldots \mathrm{n}
\end{aligned}
$$

Jumlah pendapatan ditabulasi secara sederhana, yaitu dengan menghitung pendapatan pengusaha pada usaha walet terhadap pendapatan keluarga di daerah penelitian.

Dan untuk menjawab tujuan ketiga, yaitu mengetahui persepsi masyarakat terhadap keberadaan usaha sarang burung walet dapat diukur dengan metode kuantitatif, pengukuran skala persepsi dengan menggunakan skala likert (Riduwan, 2008).

Skor penilaian tingkat persepsi masyarakat diukur dengan menggunakan skala Likert. Responden dengan jumlah 36 orang diminta untuk mengisi kuesioner yang berisi pernyataan-pernyataan untuk menilai keberadaan usaha sarang burung walet guna membentuk proporsi nilai. Kriteria untuk setiap tanggapan masing-

\begin{tabular}{|c|c|c|c|c|c|}
\hline \multirow{2}{*}{\multicolumn{2}{|c|}{ Variabel }} & \multirow{2}{*}{ Indikator } & \multicolumn{3}{|c|}{ Alternatif Jawaban } \\
\hline & & & $\mathbf{S}$ & $\mathbf{N}$ & TS \\
\hline \multirow[t]{4}{*}{ a. } & Suara & $\begin{array}{l}\text { 1. Adanya suara yang ditimbulkan oleh } \\
\text { burung walet }\end{array}$ & 1 & 2 & 3 \\
\hline & & $\begin{array}{l}\text { 2. Adanya suara yang ditimbulkan oleh } \\
\text { kaset pemanggil burung walet }\end{array}$ & 1 & 2 & 3 \\
\hline & & $\begin{array}{l}\text { 3. Adanya pengaturan batasan waktu untuk } \\
\text { suara kaset pemanggil }\end{array}$ & 1 & 2 & 3 \\
\hline & & $\begin{array}{l}\text { 4. Adanya batasan maksimal volume suara } \\
\text { kaset pemanggil burung walet }\end{array}$ & 1 & 2 & 3 \\
\hline \multirow[t]{4}{*}{ a. } & Bangunan & $\begin{array}{l}\text { 1. Limbah Burung Walet yang berserakan } \\
\text { dimana-mana }\end{array}$ & 1 & 2 & 3 \\
\hline & & 2. Bangunan jauh dari permukiman & 1 & 2 & 3 \\
\hline & & $\begin{array}{l}\text { 3. Bangunan tidak berdekatan dengan } \\
\text { sarana public }\end{array}$ & 1 & 2 & 3 \\
\hline & & $\begin{array}{l}\text { 4. Bangunan tidak berdekatan dengan } \\
\text { perkantoran }\end{array}$ & 1 & 2 & 3 \\
\hline \multirow[t]{3}{*}{ b. } & Penyakit & 1. Ancaman terkena virus flu burung & 1 & 2 & 3 \\
\hline & & $\begin{array}{l}\text { 2. Ancaman penyakit akibat kurangnya } \\
\text { kebersihan di bangunan walet }\end{array}$ & 1 & 2 & 3 \\
\hline & & $\begin{array}{l}\text { 3. Ancaman terserang nyamuk malaria dan } \\
\text { DBD yang berkembang biak di bak-bak }\end{array}$ & 1 & 2 & 3 \\
\hline
\end{tabular}
masing kategori adalah $3=$ tidak setuju, $2=$ netral/tidak tau/ tidak jawab, $1=$ setuju.

Tabel 1. Pernyataan Persepsi Masyarakat Terhadap Usaha Sarang Burung Walet. 
tempat penampungan air yang terdapat

di dalam bangunan
Keterangan:
Setuju
Netral, tidak tau/tidak jawab
Tidak setuju

$$
\begin{array}{ll}
(\mathrm{S}) & =1 \\
(\mathrm{~N}) & =2
\end{array}
$$$$
(\mathrm{TS})=3
$$

Jawaban responden dihitung kemudian dikelompokan sesuai kriteria. Dari kriteria didapatkan bobot nilai yang mengindikasikan keberadaan usaha sarang burung walet. Persepsi masyarakat terhadap usaha sarang burung walet berdasarkan data yang diperoleh dari 11 pertanyaan berkisar antara 11 sampai dengan 33 .

Jumlah skor minimum $\quad: 36 \mathrm{x}$ $11 \times 1=396$

Jumlah skor maksimum $\quad: 36 \mathrm{x}$ $11 \times 3=1188$

Secara matematis untuk menjawab model skoring skala likert maka digunakan rumus skala interval, sedangkan skala interval itu sendiri menurut Sudjana (2005), adalah skala yang memiliki interval atau jarak yang sama antara kategori titik-titik terdekatnya, dalam penelitian ini untuk menentukan panjang interval kelas menurut
Sudjana (2005), digunakan rumus sebaga berikut:

$$
\mathrm{i}=\frac{\operatorname{Jarak}}{\text { Jumlah Kelas }}
$$

Keterangan:

$\mathrm{i}=$ Interval kelas

Jarak $\quad=$ Jumlah skor

maksimum dikurangi jumlah skor minimum

Jumlah Kelas $=$ Jumlah interval atau kategori yang ditentukan

Berdasarkan 11 item pertanyaan dimana jumlah skor maksimum 44 dengan jumlah tiga kelas dikurangi skor minimum 11 sehingga diperoleh nilai interval kelas 33. Adapun penilaian skor skala likert usaha sarang burung alet adalah sebagai berikut.

Tabel 2. Penilaian Skor Skala Likert

\begin{tabular}{llc}
\hline No & Skor & Usaha Sarang Burung Walet di Desa Rantau Katang \\
\hline 1 & $395-660$ & Setuju \\
2 & $661-926$ & Netral \\
3 & $927-1191$ & Tidak Setuju \\
\hline
\end{tabular}

\section{HASIL DAN PEMBAHASAN}

\section{Kondisi usaha sarang burung walet di Desa Rantau Katang}

Desa Rantau Katang memiliki jumlah penduduk sebanyak 1085 orang. Kegiatan usaha sarang burung walet adalah kegiatan yang menguntungkan bagi masyarakat yang memiliki modal karena hasilnya yang sangat menjanjikan. Dari 15 orang pelaku usaha sarang burung walet di desa Rantau Katang diambil sampel 5 pengusaha. Pertimbangan dalam memilih 5 orang pengusaha dikarenakan karakteristik yang sama. 
Tabel 3. Karakteristik Pengusaha Walet Warga di Desa Rantau Katang, Tahun 2017

\begin{tabular}{clcc}
\hline No & Pekerjaan & Jumlah Bangunan & Lama Usaha \\
\hline 1 & Petani & 1 unit & $2013-2017$ \\
2 & Pedagang & 1 unit & $2014-2017$ \\
3 & Wiraswasta & 1 unit & $2013-2017$ \\
4 & Wiraswasta & 1 unit & $2014-2017$ \\
5 & Petani & 1 unit & $2014-2017$ \\
\hline
\end{tabular}

Sumber : Data Primer yang diolah, 2018

Berdasarkan Tabel 3 dapat dilihat bahwa dari 5 jumlah responden pengusaha di Desa Rantau Katang bekerja sebagai petani, pedagang dan wiraswasta. Dari 5 orang pengusaha tersebut rata-rata

\section{Umur Responden}

Tabel 4. Umur Responden di Desa Rantau Katang Tahun 2017

\begin{tabular}{ccc}
\hline Uraian & $\begin{array}{c}\text { Jumlah } \\
\text { (orang) }\end{array}$ & $\begin{array}{c}\text { Persentase } \\
(\boldsymbol{\%})\end{array}$ \\
\hline Umur Responden (tahun) & & \\
a. $15-30$ & 16 & 39,02 \\
b. $31-50$ & 12 & 29,27 \\
c. $>51$ & 13 & 31,70 \\
\hline Total & $\mathbf{4 1}$ & $\mathbf{1 0 0 , 0 0}$ \\
\hline
\end{tabular}

Sumber: Data Primer yang Diolah, 2017

Berdasarkan Tabel 4. diketahui jumlah seluruh responden 41 orang, tapi mayoritas berada pada kriteria umur produktif (umur 15-64 tahun) sebanyak 16 responden $(39,02 \%)$. Artinya, responden yang terpilih merupakan orang yang mengerti keadaan desa Rantau Katang. Oleh karena itu, responden dapat memberikan tanggapan yang tepat mempunyai sebanyak 1 unit bangunan rumah walet. Rata - rata dari 5 orang pengusaha tersebut lama usaha waletnya mulai dari 3 - 4 tahun.

mengenai usaha sarang burung walet. 


\section{Kondisi Bangunan Sarang Burung Walet}

Tabel 5. Karakteristik Bangunan Sarang Burung Walet

\begin{tabular}{clcccc}
\hline No & $\begin{array}{c}\text { Jenis } \\
\text { Bangunan }\end{array}$ & Ukuran & Tingkat & $\begin{array}{c}\text { Nilai Bangunan } \\
(\mathbf{R p})\end{array}$ & Lama Usaha \\
\hline 1 & Beton & $4 \times 6$ & 4 tingkat & 100.000 .000 & $2013-2017$ \\
2 & Beton & $5 \times 6$ & 3 tingkat & 80.000 .000 & $2014-2017$ \\
3 & Semi Beton & $4 \times 5$ & 4 tingkat & 70.000 .000 & $2013-2017$ \\
4 & Beton & $5 \times 5$ & 6 tingkat & 150.000 .000 & $2014-2017$ \\
5 & Semi Beton & 4 x 6 & 4 tingkat & 77.000 .000 & $2014-2017$ \\
\hline
\end{tabular}

Sumber: Data Primer yang Diolah, 2017

Berdasarkan Tabel 5, dari data 5 orang responden yang masing-masing memiliki satu unit bangunan sarang burung walet. Bangunan terbuat dari beton dan juga semi beton (menggunakan dinding seng atau kayu). Bangunan sarang burung walet di desa Rantau Katang rata-rata berusia 3-4 tahun. Bangunan sarang burung walet yang paling besar adalah jenis beton, berukuran 5 x 5 dan 6 tingkat biaya kurang lebih $\mathrm{Rp}$ 150.000.000, dan yang paling murah adalah bangunan jenis semi beton, ukuran 4 x 5 dan 4 tingkat dengan nilai bangunan $\mathrm{Rp}$ 70.000.000.

Pola pemanenan sarang burung walet dilakukan rata-rata sebanyak 6 kali dalam setahun dilakukan sendiri oleh pemilik. Hasil panen sarang burung walet biasanya dijual kepada pengepul. Hambatan yang dialami oleh kebanyakan pengusaha sarang burung walet di desa adalah masalah keamanan hal tersebut di akui karena sarang burung walet yang bernilai sangat mahal di pasaran.

\section{Alat Dan Perlengkapan Yang Digunakan Pada Usaha Sarang Burung Walet}

Tabel 6 Alat Dan Perlengkapan Pada Usaha Sarang Burung Walet

\begin{tabular}{ll}
\hline \multicolumn{1}{c}{ Uraian } \\
\hline Alat & Skrap \\
& Senter kepala \\
& Tangga aluminium \\
& Speaker walet/satuan \\
& Ampli \\
Kabel/meter \\
Flaskdisk \\
Pompa air \\
Pakan/serbuk serangga \\
Parfum walet \\
Pembasmi hama \\
Listrik
\end{tabular}

Berdasarkan Tabel 6 dapat dilihat bahwa usaha sarang burung walet meliputi alat-alat yang digunkan untuk memanggil burung walet seperti speaker, ampli dan sebagainya. Selanjutnya yang digunakan untuk pemanenan seperti tangga, senter kepala, skrap dan parfum walet.

Tangga digunakan untuk memanjat saat memanen sarang burung walet karena 
posisi sarang burung yang berada di langitlangit. Selain itu bangunan sarang burung walet dibuat tinggi rata-rata 2,5-3 meter pertingkat. Harga tangga aluminium dipasaran berkisar Rp. 450.000 .

Senter kepala diperlukan saat pemanenan sarang burung karena kondisi didalam bangunan yang gelap. Tujuan ruangan yang gelap adalah agar lebih menyerupai habitat burung walet yang terbiasa tinggal di dalam gua. Harga senter kepala dipasaran berkisar Rp. 75.000.

Skrap adalah alat yang digunakan untuk mengambil sarang burung walet agar tidak rusak. Skrap terbuat dari bahan seng sedangkan gagangnya terbuat dari plastik. Sarang burung walet bertekstur keras namun mudah patah oleh karena itu, proses memanennya harus menggunakan skrap dengan hati-hati. Harga skrap dipasaran berkisar Rp. 175.000.

Speaker, ampli, listrik, flaskdisk dan kabel merupakan paket sound sistem yang diperlukan sebagai alat pemanggil memanggil burung walet. paket sound sistem ini diletakan didalam bangunan agar burung walet tertarik untuk memasuki bangunan sarang burung walet. Paket sound sistem ini memutar suara burung walet yang filenya disimpan didalam flaskdisk. Suara burung walet ada yang diputar sepanjang hari dan ada juga dihidupkan pada waktu tertentu. Alasan diputar pada waktu tertentu karena usaha sarang burung walet berada di dekat permukiman warga.

Pompa air diperlukan untuk mengisi air didalam kolam yang berada didalam bangunan. Kolam dibuat didalam bangunan agar bangunan sarang burung walet tetap sejuk menyerupai tempat habitat asal burung walet seperti di gua. Kolam dibuat cukup dangkal tidak sampai 1 meter. Harga pompa air dipasaran berkisar Rp. 450.000.

Pakan/serbuk serangga merupakan pakan serangga yang ditabur dilantai bangunan. Pakan ini merupakan umpan untuk memancing serangga, dimana serangga inilah yang menjadi makanan burung walet. harga pakan ini dipasaran berkisar Rp. 500.000 .

Pembasmi hama untuk membasmi hama yang mengganggu burung walet. Seringkali bangunan burung walet didatangi oleh beberapa hama seperti tikus, burung hantu dan sebagainya. Tikus bisanya memakan telur dan anak walet yang baru menetas. Sedangkan burung hantu yang masuk kedalam bangunan menyebabkan burung walet pergi karena merasa terganggu. Harga pembasmi hama dipasaran berkisar Rp. 70.000.

Parfum walet biasanya dipergunakan setelah pemanenan untuk mengurangi resiko burung walet terganggu dengan baubau yang bisa mempengaruhi dan membuat burung walet terganggu setelah proses pemanenan. Harga parfum walet yang biasa digunakan pengusaha sarang burung walet adalah diamon dengan kisaran harga Rp. 525.000 .

\section{Kualitas Produksi Sarang Burung Walet}

Pengusaha sarang burung walet di Desa Rantau Katang menghasilkan tiga jenis kualitas sarang burung walet yaitu: Kualitas A, kualitas B dan Kualitas C.

Harga sarang burung walet ditentukan dari kualitasnya. Pengusaha walet di Desa Rantau Katang lebih banyak menghasilkan sarang burung walet kualitas A.

Kualitas A memiliki ciri-ciri berbentuk mangkok, tidak memiliki cacat dan berwarna putih. Kualitas A adalah kualitas yang terbaik dan yang paling mahal. Kisaran harganya adalah Rp. $12.000 .000 / \mathrm{Kg}$.

Kualitas B memiliki ciri-ciri berbentuk segitiga karena biasanya terletak dibagian sudut. Kualitas ini bisanya tidak 
banyak dihasilkan. Kisaran harga sarang burung walet kualitas $\mathrm{B}$ adalah $\mathrm{Rp}$. $10.000 .000 / \mathrm{Kg}$.

Kualitas $\mathrm{C}$ adalah sarang burung walet yang rusak. Kualitas C biasanya akibat proses pemanenan yang kurang baik. Harga dipasaran biasanya Rp. 5.400.000 $/ \mathrm{Kg}$.

\section{Pendapatan pengusaha di Desa Rantau Katang}

Pendapatan usaha ternak walet yaitu penghasilan dari kegiatan produksi yang dilakukan pengusaha dan merupakan penerimaan dikurang dengan biaya yang dikeluarkan untuk usahanya. Berdasarkan hasil penelitian ada lima pengusaha walet yang di ambil dari Desa Rantau Katang.

\section{a. Analisis Penerimaan Usaha Sarang Burung Walet}

Penerimaan adalah perkalian antara produksi yang dihasilkan dengan harga jual dan biasanya produksi berhubungan negatif dengan harga, artinya harga akan turun ketika produksi berlebihan. Hal tersebut dapat dilihat pada tabel.

Tabel 7. Rata-Rata Penerimaan/Tahun dari Usaha Walet di Desa Rantau Katang, Tahun 2017

\begin{tabular}{ccc}
\hline Produksi(Kg) & Harga $($ Rp) & Penerimaan $(\mathbf{R p})$ \\
\hline 5,80 & $11.000 .000,00$ & $63.800 .000,00$
\end{tabular}

Sumber : Data primer yang diolah, 2018

Pada Tabel 7 menunjukkan bahwa sarang burung walet yang dihasilkan selama 1 tahun rata-rata sebanyak $5,8 \mathrm{~kg}$ dengan rata-rata harga Rp. 11.000 .000 per $\mathrm{kg}$ dan rata-rata penerimaan setahun adalah Rp. 63.800.000. Sarang burung walet yang dihasilkan di hitung secara Ramas dengan harga yang sudah di tetapkan berdasarkan kerjasama antara pengusaha dan pembeli.

\section{b. Analisis Biaya Usahatani}

Tabel 8 Rata-Rata Biaya Total/Tahun Dari Usaha Walet di Desa Rantau Katang, Tahun 2017

\section{Uraian}

\section{Biaya Total (RP)}

$\begin{array}{lr}\text { Pakan } & 590.000 \\ \text { Listrik } & 2.208 .000 \\ \text { Obat dan lainya } & \end{array}$

Obat dan lainya

977.000

\section{Rata-Rata}

3.775.000
total usaha sarang burung walet meliputi seluruh biaya tetap dan biaya variabel. Besarnya biaya total usaha sarang burung walet dalam satu tahun dapat dilihat pada Tabel 8.

Sumber : Data primer yang diolah, 2018 
Dari Tabel 8dapat dilihat biaya yang dikeluarkan pada usaha ternak walet yaitu rata-rata sebesar Rp. 3.775.000 yang terdiri biaya untuk pembelian pakan berupa serbuk penumbuh serangga pakan walet sebesar Rp.590.000, listrik sebesar Rp. 2.208.000, serta obat dan lainnya sebasar Rp. 977.000 selama setahunnya dalam tahun 2017.

\section{c. Analisis Pendapatan Usaha Sarang Burung Walet \\ Besarnya pendapatan atau} keuntungan yang diperoleh dengan cara mengurangi penerimaan yang diperoleh dengan biaya total. Selengkapnya perhitungan pendapatan usaha walet disajikan pada lampiran, sedangkan secara rinci seperti pada Tabel 9.

Tabel 9. Pendapatan Rata-Rata/Tahun dari Usaha Walet di Desa Rantau Katang, Tahun 2017

\begin{tabular}{ccc}
\hline No & Uraian & Nilai Rata-Rata (Rp) \\
\hline 1 & Penerimaan & 63.800 .000 \\
2 & Biaya Total & 3.775 .000 \\
\hline & Pendapatan & 60.025 .000 \\
\hline
\end{tabular}

Sumber : Data primer yang diolah, 2018

Dari Tabel 9. dapat dilihat bahwa penerimaan rata-rata dari usaha walet sebesar Rp. 63.800.000 dan biaya Total rata-rata sebesar Rp. 3.775 .000 dengan demikian diperoleh besarnya pendapatan usaha walet di Desa Rantau Katang dalam tahun 2017 rata-rata sebesar Rp. 60.025.000.

\section{Persepsi masyarakat terhadap keberadaan usaha sarang burung walet di Desa Rantau Katang}

Persepsi responden yang dimaksud dalam penelitian ini adalah berupa persepsi dari responden di Desa Rantau Katang terhadap keberadaan usaha sarang burung walet berdasarkan pengetahuan dan informasi-informasi kegiatan usaha sarang burung walet selama responden bertempat tinggal di Desa tersebut. Persepsi responden terhadap usaha sarang burung walet merupakan hal mendasar untuk menilai persepsi responden mengenai keberadaan usaha sarang burung walet disekitar permukiman.

Sikap responden yang dimaksud dalam penelitian ini adalah berupa sikap dari responden di Desa Rantau Katang terhedap keberadaan usaha sarang burung walet berdasarkan pengetahuan dan informasi terhadap kegiatan usaha sarang burung walet selama responden bertempat tinggal di Desa tersebut. Untuk lebh jelas jumlah responden yang menentukan persepsi masyarakat terhadap indikator suara usaha sarang burung walet, dapat dilihat pada Tabel 10.

Tabel 10. Persepsi Responden Terhadap Indikator Suara

\begin{tabular}{lllc}
\hline No & Skor & Kriteria & Total Skor Persepsi \\
\hline 1 & $144-240$ & Setuju & \\
2 & $241-337$ & Netral & 263 \\
3 & $338-434$ & Tidak Setuju & \\
\hline
\end{tabular}


Sumber : Data primer yang diolah, 2018

Berdasarkan Tabel 10 dapat dilihat dari 36 responden di desa Rantau Katang tahun 2017 menyatakan "netral" dengan total skor 263 terhadap keberadaan sarang burung walet karena suara yang ditimbulkan oleh usaha sarang burung walet memang diperlukan untuk memeanggil burung walet datang ke bangunan asalkan dilakukan penjadwalan waktu suara bisa di bunyikan atau dimatikan. Beberapa hal yang diperhatikan yaitu adanya pengaturan waktu dihidupkan suara dari speaker pemanggil burung walet pada jam tertentu agar tidak mengganggu waktu istirahat masyarakat di lingkungan sekitar bangunan sarang burung walet.

Untuk lebih jelas jumlah responden yang menentukan persepsi pada indikator bangunan, dapat dilihat pada Tabel 11 .

Tabel 11. Persepsi Responden Terhadap Indikator Bangunan

\begin{tabular}{lllc}
\hline No & Skor & Kriteria & Total Skor Persepsi \\
\hline 1 & $144-240$ & Setuju & 216 \\
2 & $241-337$ & Netral & \\
3 & $338-434$ & Tidak Setuju & \\
\hline
\end{tabular}

Sumber : Data primer yang diolah, 2018

Berdasarkan Tabel 5.3.2. dapat dilihat bahwa persepsi reponden terhadap indikator bangunan usaha sarang burung walet responden menyatakan "setuju" dengan total skor 216 yang berarti responden memiliki persepsi yang baik terhadap indikator banguan usaha sarang burung walet di Desa Rantau Katang. Sebagian besar mayoritas persepsi

\begin{tabular}{llll}
\hline No & Skor & Kriteria & Total Skor Persepsi \\
\hline 1 & $108-180$ & Setuju & \\
2 & $181-253$ & Netral & 295 \\
3 & $254-326$ & Tidak Setuju & \\
\hline
\end{tabular}

Sumber : Data primer yang diolah, 2018

masyarakat terhadap bangunan sarang burung walet mesti ada penertiban agar tidak mengganggu fasilitas umum. Bangunan sarang burung walet setidaknya berada dijarak 100 dari permukiman.

Untuk lebih jelas jumlah responden yang menentukan persepsi pada indikator bangunan, dapat dilihat pada Tabel 12 .
Berdasarkan Tabel 12 dapat dilihat bahwa persepsi responden terhadap indikator penyakit responden mengatakan"tidak setuju" dengan total skor 295 terhadap semua indikator penyakit yang berarti responden memiliki persepsi yang tidak baik terhadap indikator penyakit usaha sarang burung walet di Desa Rantau Katang. Para pengusaha sarang burung walet harus selalu menjaga kebersihan bangunan sarang burung walet agar tidak menimbulkan ancaman penyakit terhadap lingkungan sekitar. Mayoritas responden tidak setuju dikarenakan ancaman penyakit yang ditimbulkan cukup berbahaya seperti flu burung, deman berdarah dan sebagainya.. 
Untuk lebih jelas total skor yang menentukan persepsi responden terhadap usaha sarang burung walet, dapat dilihat pada Tabel 13.

Tabel 13. Total Skor Persepsi Responden Terhadap Usaha Sarang Burung Walet

\begin{tabular}{lllc}
\hline No & Skor & Kriteria & Total Skor Persepsi \\
\hline 1 & $395-660$ & Setuju & \\
2 & $661-926$ & Netral & 774 \\
3 & $927-1191$ & Tidak Setuju & \\
\hline
\end{tabular}

Sumber : Data primer yang diolah, 2018

Berdasarkan tabel 5.3.4 dapat dilihat bahwa total skor persepsi responden berkategori "netral" dengan total skor 774 yang berarti responden memiliki sikap netral, tidak tau atau tidak jawab terhadap keberadaan usaha sarang burung walet di Desa Rantau Katang. Hal ini disebabkan keberadaan usaha sarang burung walet tidak menimbulkan dampak yang negatif dimasyarakat karena hal-hal yang sudah disepakati disekitar lingkungan usaha sarang burung walet. Dengan keberadaan usaha sarang burung walet dapat meningkatkan perekonomian masyakat di Desa Rantau Katang.

\section{KESIMPULAN}

1. Kondisi usaha sarang burung walet di Desa Rantau Katang adalah: pola pemanenan dilakukan rata-rata sebanyak 6 kali dalam setahun, rata-rata memiliki satu buah bangunan yang telah diusahakan 3-4 tahun, dan produksi didominasi oleh kualitas A.

2. Rata-rata pendapatan usaha sarang burung walet di Desa Rantau Katang sebesar Rp. 60.025.000/tahun. Adapun rata-rata biaya total eksplisit adalah $\mathrm{Rp}$. 3.775.000 dan penerimaannya adalah sebesar Rp. 63.800.000/tahun.
3. Persepsi masyarakat di Desa Rantau Katang terhadap keberadaan usaha sarang burung walet adalah berada pada kategori "netral" dengan dengan total 774 yang berarti responden memiliki sikap netral terhadap keberadaan usaha sarang burung walet di Desa Rantau Katang. Adapun rinciannya adalah sebagai berikut:. (a) Persepsi reponden terhadap indikator suara usaha sarang burung walet responden kriteria "netral" dengan total skor 263 yang berarti responden memiliki persepsi yang netral terhadap indikator suara usaha sarang burung walet di Desa Rantau Katang. (b) Persepsi reponden terhadap indikator bangunan usaha sarang burung walet dengan dengan total skor 216 responden dengan kriteria "setuju" yang berarti responden memiliki persepsi yang baik terhadap indikator banguan usaha sarang burung walet di Desa Rantau Katang. (c) Persepsi responden terhadap indikator penyakit dengan dengan total skor 295 kriteria "tidak setuju" yang berarti responden memiliki persepsi yang tidak baik terhadap indikator penyakit usaha sarang burung walet di Desa Rantau Katang.

DAFTAR PUSTAKA 
Notoatmodjo, S. 2010. Metodologi Penelitian Kesehatan. Rineka Cipta. Jakarta.

Riduwan.2008. Skala Pengukuran Variabel-variabel Penelitian. Penerbit Alfabeta, Bandung.

Soehartono, I. 1995. Metode Penelitian Sosial. Remaja Rosdakarya. Bandung.

Soekartawi. 1995. Prinsip Dasar Perencanaan Pembangunan. Rajawali. Jakarta.
Sudjana. 2005. Metode Statistik. Tarsito. Bandung.

Sunarto. 2005. Pengertian Persepsi. (Http://infoskripsi.com. Diakses tanggal 15 Oktober 2017).

TRUBUS. 2009. Harga Sarang Burung Walet. (Http://www.trubusonline.co.id. Diakses tanggal 15 Oktober 2017). 